\title{
Intergenerational analysis of patronymic transformations in the Quebec (Canada) population since the $17^{\text {th }}$ century
}

\author{
Marc Tremblay \\ Université du Québec à Chicoutimi, Canada
}

\begin{abstract}
Surnames may undergo several transformations over time. Thus, patronymic distributions observed in a population at a given time may hide changes that occurred previously, the extent of which can be estimated with intergenerational data. Using a corpus of 5,100 deep-rooted ascending genealogies from the Quebec (Canada) population, this study compares contemporary surnames with those of founding ancestors in each paternal line and identifies various patronymic mutations occurring over multiple generations. On average, paternal lines go back eight generations. About one third of all paternal lines presented at least one orthographic difference between the contemporary and the original surnames. Many surnames were transformed several times in a single paternal line, and some changes were different for a given surname along different lines. Most changes occurred among the first generations following the founding ancestors. Regional comparisons also show important variations.
\end{abstract}

Keywords: patronyms, family names, surnames, genealogies, intergenerational, generations, Quebec population 


\section{Introduction}

Patronymic data are frequently used for studies in historical demography (see, for example, Darlu, 2004; Longley et al., 2007; Roman-Busto, 2015), evolutionary anthropology (Prost et al., 2008; Cheshire et al., 2011), and population genetics (King et al., 2006; Darlu et al., 2012; Martinez-Cadenas et al., 2016). Among the underlying assumptions common to this type of study are the single origin of each family name (often unverified) and the stability of its spelling over generations within a population. In truth, not all surnames are immutable. For various reasons, including those related to the linguistic distance between some newcomers and the host society, a given surname may undergo several transformations, translations or substitutions over time (Desjardins et al., 2000; Picard, 2012). In some cases, it may prove difficult to make the connection between a contemporary surname and the ancestral one from which it derived. Thus, patronymic distributions observed in a population at a given time may hide significant changes that occurred in a more or less distant past (Picard, 2007a; Dipierri et al., 2011; Lucchetti et al., 2011; Parkin, 2015; Solé-Morata et al., 2015).

The extent and impact of these changes may be difficult to assess for a whole population over a long period. Here we show that intergenerational data may be useful for such an investigation. A corpus of 5,100 ascending genealogies from the Quebec (Canada) population was reconstructed using data from the BALSAC population register (BALSAC, 2016). The main objectives of this study were to compare contemporary surnames with those of the founding ancestors in each paternal line and identify patronymic changes occurring over multiple generations.

\section{The Quebec population}

The province of Quebec is located in the eastern part of Canada (Figure 1). The vast majority of its population of 8.5 million descends from French pioneers who settled in New France during the $17^{\text {th }}$ and $18^{\text {th }}$ centuries (Charbonneau et al., 2000). After the takeover by the British in 1760, French immigration came to an end, and new immigrants from the British colonies, the British Isles, Ireland and other European countries started to arrive in the province (McInnis, 2000a). Although intermarriage occurred occasionally between the newcomers and the mostly Catholic French-Canadian natives, the French-Canadian population remained relatively isolated and maintained high fertility levels well into the $20^{\text {th }}$ century (McInnis, 2000b; Kerr and Beaujot, 2016). As a result, most surnames in the contemporary Quebec population have a French origin (Duchesne, 2006).

Many of these contemporary French surnames have remained unchanged since their introduction to New France by the first French pioneers (Desjardins et al., 2000; Picard, 2007a). But some surnames have been modified over time. Surnames from other origins have also been altered, sometimes drastically. For example, German surnames, introduced in the Quebec population by German mercenaries who were recruited by the British army during the American revolution, were so different from the French surnames that some were translated into French or significantly transformed (Jacob, 2006 and 2015; Picard, 2007b). Although some research has been done about these surname changes in the population of Quebec, little is known about their relative frequency and when they occurred. 


\section{Data and methods}

Data for this study were obtained from a corpus of 5,100 ascending genealogies. The starting points of the genealogies (the subjects) are individuals who were married in one of the seventeen Quebec regions (see Figure 1) between 1966 and 1985. ${ }^{1}$ The genealogies (300 for each region) were reconstructed using data from the BALSAC population register (BALSAC, 2016). This register contains genealogical information about the Quebec population going back to the early $17^{\text {th }}$ century. It was constructed from marriage, baptism and death records transcribed in parish registers since the beginning of French colonization (Bouchard et al., 1995; Charbonneau et al., 2000).

Genealogies were reconstructed up to the first immigrants who came to Quebec. Thus, in most cases, the genealogical branches go back to the $17^{\text {th }}$ century, reaching the first French pioneers. Patronymic data were analyzed in all paternal lines. The surnames of the contemporary subjects, as written in their marriage certificates, were compared with those of the immigrant ancestors identified in each paternal line. Results of these comparisons were then classified into three categories:

1) no change

2) minor change (spelling variation with no or with only a slight difference in the pronunciation of the surname)

3) major change (in both spelling and pronunciation). ${ }^{2}$

Distribution of results in each of the seventeen regions were calculated and compared. Detailed examples were selected to illustrate and explain some of the observed changes.

\section{Results}

On average, paternal lines in the Quebec genealogies go back some 8 generations (Table 1). Results show that in most cases, there is no difference between the surnames introduced by immigrant ancestors and that of their contemporary descendants. However, the proportion of surnames that remained unchanged varies significantly according to the region, from $55.7 \%$ (Outaouais) to $79.7 \%$ (Saguenay-Lac-St-Jean). Regions located in the eastern part of the province (see Figure 1) tend to show the lowest proportions of surname changes. At the opposite, genealogies from the western regions (in an around Montreal) have higher proportions of changes. Results also show that, with a few exceptions, most of the changes observed in the regional genealogies are not minor. Up to two thirds of all changes are considered major.

Table 2 shows some examples of patronymic changes observed in the Quebec genealogies. Each example represents one paternal line, the length of which varies according to the number of generations separating the subject (generation 0) from his/her paternal immigrant ancestor (generations 4 to 10). Examples are presented in alphabetical order of the subject's surname. Surnames of all ancestors in each paternal line are showed as they appear in the marriage records. The geographical origin of all immigrant ancestors (end of the paternal lines) are provided. Most of the surnames have a French origin, but examples from other origins are also given. 
The first three surnames appearing in Table 2 are examples of minor changes. In these examples, the spelling of the immigrant ancestors' surname is different from that of his contemporary descendant, but the pronunciation is similar. However, comparison of the subject's and immigrant's surnames may hide some changes that occurred along the paternal line but disappeared in the following generations. An example of such changes can be seen in the BELL line: at the third and fourth generations, the surname extension LAGRENADE appeared with BEL, but was no longer there at the second generation, where the surname BELLE was observed (the final letter $\mathrm{E}$ was dropped afterwards). Such multiple changes in a single line can be observed in many of the examples shown in Table 2.

Some contemporary surnames are completely different from their original form. For example, BOULANGER vs. LEFEBVRE, CHAMPAGNE vs. LAPLANTE or SANSCARTIER vs. PAYSAN. In some cases, identical contemporary surnames may come from very different original surnames, as is the case for LAFRANCE (from DARAGON, DUBOIS or PINEL). Conversely, identical original surnames may have been transformed quite differently along different lines of descendants, as for LEFEBVRE which became BOULANGER in one line and DESCOTEAUX in another line.

These examples show that many original French surnames were transformed radically over generations, but surnames from other origins were generally transformed more frequently than French surnames. Original German surnames appearing in Table 2, such as WEBER (which became BERNARD), SHUMPF (JOMPHE) or HILDEBRAND (LEBLANC) are good examples. In the WEBER-BERNARD case, it is interesting to note that BERNARD is the first name of the immigrant WEBER and appeared subsequently as part of his grandson's surname. Another interesting case is that of SERRURIER SELOZ, whose original surname was probably SCHLOSS or SCHLOSSER (meaning locksmith or serrurier in French) which became MASSON.

English surnames were also transformed, such as JAMES SANSOUCY LANGLOIS to GEMME (which is phonetically similar to JAMES), or OUABARD LANGLOIS to LANGLAIS. In these examples, LANGLOIS and LANGLAIS are French terms meaning 'the English'. Other examples include NUHALTE (from Yorkshire) which became THISDELLE and HAYISMAN (from Ireland) transforming into ESMOND.

One last interesting example is that of SEIZE which became LOUIS SEIZE. The first name of the immigrant ancestor is LOUIS, who was married in 1763. His son was married in 1790 and adopted the surname LOUISSEIZE, evidently combining the first and last names of his father. Incidentally though, the French King Louis XVI began his reign in 1774: one may thus assume that the surname LOUIS SEIZE (seize meaning sixteen) was also chosen in honor of the French king.

\section{Conclusion}

This study of intergenerational patronymic changes provided new insights about the relative frequency and the nature of surname transformations in the Quebec population over a period of nearly four centuries. Although most of the original surnames remained intact during the whole period, many surnames have undergone important alterations. Regional comparisons showed that 
surnames were more frequently transformed among the populations of the western regions of Quebec than among those from the eastern part. This may be explained by the fact that immigration and migratory movements in general have been much more important in the western regions of the province, resulting in a greater diversity of surnames in these regions (Gagnon and Heyer, 2001; Henripin, 2003; Duchesne, 2006).

Results also showed that surname changes can occur several times in a single paternal line. Hence, simple comparisons of contemporary surnames with the original surnames may hide other intergenerational changes. These multiple changes can be detected with continuous genealogical data, as the examples presented in Table 2 have shown. Such observations also reveal the timing of surname changes. In the Quebec population, the most significant changes occurred in the first generations following the original bearers of the surnames, which may be explained in part by the fact that literacy was not as common during the $17^{\text {th }}$ and $18^{\text {th }}$ centuries than during the following centuries. In the case of non-French immigrants, integration to the dominant French-Canadian community may also have played a role in the francization of their surnames (Picard 2007b). Another factor which can explain the relative stabilization of surnames in the last generations is a directive issued by the Quebec authorities in 1870, stipulating that families should use only one single surname for administrative purposes (Desjardins et al., 2000). Despite this directive, results showed that some changes also occurred among the recent generations.

\section{Notes}

${ }^{1}$ Further details about the construction and characteristics of these genealogies can be found in Tremblay (2014a and 2014b).

2 The categorization of changes in surnames was based primarily on differences in spelling as they were observed in marriage certificates. Although some surnames may have been pronounced differently in the past, changes in the pronunciation of surnames were identified using contemporary references. For more information on the pronunciation of Québec surnames, see Jacob (2006; 2015). Morin (1996; 2002) also provides useful details on the evolution of the French language in Québec since the $17^{\text {th }}$ century.

\section{Acknowledgements}

The author wishes to thank Ève-Marie Lavoie, Jean-Sébastien Bournival, Gabrielle Rouleau and Ariane Néron-Lapointe for their technical assistance. Many thanks also to the two anonymous reviewers for their useful suggestions. This research was supported by the Social Sciences and Humanities Research Council of Canada under Grant number 435-2012-0749.

\section{Bibliography}

BALSAC. 2016. BALSAC Population Database.<http://balsac.uqac.ca/english>; last accessed on 2 July 2016.

Bouchard, Gérard, Raymond Roy, Bernard Casgrain, and Michel Hubert. 1995. "Computer in Human Sciences: From Family Reconstitution to Population Reconstruction.” In From 
Information to Knowledge. Conceptual and Content Analysis by Computer. Ed. E. Nissan and K. M. Schmidt, 201-226. Oxford: Intellect.

Charbonneau, Hubert, Bertrand Desjardins, Jacques Légaré, and Hubert Denis. 2000. “The Population of the St-Lawrence Valley, 1608-1760.” In A Population History of North America. Ed. Michael R. Haines and Richard H. Steckel, 99-142. Cambridge: Cambridge University Press.

Cheshire, James, Pablo Mateos, and Paul A. Longley. 2011. "Delineating Europe’s Cultural Regions: Population Structure and Surname Clustering.” Human Biology 83: 573-598.

Darlu, Pierre. 2004. "Patronymes et Démographie Historique.” Annales de Démographie Historique 2004-2: 53-65.

Darlu, Pierre, Gerrit Bloothooft, Alessio Boattini, Leendert Brouwer, Matthijs Brouwer, Guy Brunet, Pascal Chareille, James Cheshire, Richard Coates, Kathrin Dräger, Bertrand Desjardins, Patrick Hanks, Paul Longley, Kees Mandemakers, Pablo Mateos, Davide Pettener, Antonella Useli, and Franz Manni. 2012. "The Family Name as Socio-Cultural Feature and Genetic Metaphor: From Concepts to Methods.” Human Biology 84: 169-214.

Desjardins, Bertrand, Alain Bideau, Guy Brunet, Hubert Charbonneau, and Jacques Légaré. 2000. "From France to New France: Quebec Family Names, Past and Present.” The History of the Family 5: 215-226.

Dipierri, José, Alvaro Rodriguez-Larralde, Emma Alfaro, Chiara Scapoli, Elisabetta Mamolini, Germano Salvatorelli, Graziano Caramori, Sonia De Lorenzi, Massimo Sandri, Alberto Carrieri, and Italo Barrai. 2011. "A Study of the Population of Paraguay Through Isonymy.” Annals of Human Genetics 75: 678-687.

Duchesne, Louis. 2006. Les Noms de Famille au Québec: Aspects Statistiques et Distribution Spatiale. Québec: Institut de la Statistique du Québec.

Gagnon, Alain, and Evelyne Heyer. 2001. “Fragmentation of the Québec Population Genetic Pool (Canada): Evidence from the Genetic Contribution of Founders per Region in the $17^{\text {th }}$ and $18^{\text {th }}$ Centuries.” American Journal of Physical Anthropology 114: 30-41.

Henripin, Jaques. 2003. La Métamorphose de la Population Canadienne. Montréal: Les Éditions Varia.

Jacob, Roland. 2006. Votre Nom et Son Histoire. Les Noms de Famille au Québec. Montréal: Les Éditions de l'Homme.

Jacob, Roland. 2015. Votre Nom et Son Histoire. Les Noms de Famille au Québec. Tome 2. Montréal: Les Éditions de l’Homme.

Kerr, Don, and Roderic Beaujot. 2016. Population Change in Canada. Don Mills: Oxford University Press. 
King, Turi E., Stéphane J. Ballereau, Kevin E. Schürer, and Mark A. Jobling. 2006. "Genetic Signatures of Coancestry Within Surnames.” Current Biology 16: 384-388.

Longley, Paul A, Richard Webber, and Daryl Lloyd. 2007. “The Quantitative Analysis of Family Names: Historic Migration and the Present Day Neighborhood Structure of Middlesbrough, United Kingdom.” Annals of the Association of American Geographers 97: 31-48.

Lucchetti, Enzo, Miro Tasso, Irene Amoruso, and Gianumberto Caravello. 2011. "The Border Effect in Surname Structure: An Italian-Slovenian Case Study.” Human Biology 83: 393-404.

Martinez-Cadenas, Conrado, Alejandro Blanco-Verea, Barbara Hernando, George B. J. Busby, Maria Brion, Angel Carracedo, Antonio Salas, and Cristian Capelli. 2016. "The Relationship Between Surname Frequency and Y Chromosome Variation in Spain.” European Journal of Human Genetics 24: 120-128.

McInnis, Marvin. 2000a. “The Population of Canada in the Nineteenth Century.” In A Population History of North America. Ed. Michael R. Haines and Richard H. Steckel, 371-432. Cambridge: Cambridge University Press.

McInnis, Marvin. 2000b. “Canada's Population in the Twentieth Century.” In A Population History of North America. Ed. Michael R. Haines and Richard H. Steckel, 529-599. Cambridge: Cambridge University Press.

Morin, Yves-Charles. 1996. "The Origin and Development of the Pronunciation of French in Québec.” In The Origins and Development of Emigrant Languages. Ed. Hans F. Nielsen and Lene Schøsler, 243-275. Odense: Odense University Press.

Morin, Yves-Charles. 2002. "Les Premiers Immigrants et la Prononciation du Français au Québec.” Revue Québécoise de Linguistique 31: 39-78.

Parkin, Harry. 2015. “The Fourteenth-Century Poll Tax Returns and the Study of English Surname Distribution.” Historical Methods 48: 1-12.

Picard, Marc. 2007a. "Les Noms de Famille du Canada Français: Origines et Évolution." Glottopol, Revue de Sociolinguistique en Ligne 9: 6-21.

Picard, Marc. 2007b. “On the Development of German Surnames in French Canada.” Names 55: 379-386.

Picard, Marc. 2012. “On the Translation of French-Canadian Family Names in English.” Names 60: 150-155.

Prost, Michel, Gilles Boëtsch, Marilena Girotti, and Emma Rabino-Massa. 2008. "Surname Analysis in Biological Anthropology: Alpine Populations in the $17^{\text {th }}$ and $18^{\text {th }}$ Centuries." Human Biology 80: 377-391. 
Roman-Busto, Jorge. 2015. "Influence of Changes in Political Barriers and of Geographic Distance on Kinship Inferred from Surnames and Migration Data in Olivenza, Spain, and Surrounding Portuguese Areas.” Human Biology 87: 122-31.

Solé-Morata, Neus, Jaume Bertranpetit, David Comas, and Francesc Calafell. 2015. "YChromosome Diversity in Catalan Surname Samples: Insights into Surname Origin and Frequency.” European Journal of Human Genetics 23: 1549-1557.

Tremblay, Marc. 2014a. “Les Origines Régionales Ancestrales au Québec.” Cahiers Québécois de Démographie 43: 133-161.

Tremblay, Marc. 2014b. "Regional Borders and Territorial Ancestry: A Genealogical Analysis." In Grenzen in Genealogie en Heraldiek / Frontiers in Genealogy and Heraldry / Frontières dans la Généalogie et l'Héraldique. Ed. Jan T. Anema, Rob J. F. van Drie, Roelof K. Vennik, and Bob P. M. Kernkamp, 359-368. The Hague: Stichting De Nederlandse Leeuw.

\section{Notes on Contributor}

Marc Tremblay, Ph.D. in demography, has been Professor at the Université du Québec à Chicoutimi (Québec, Canada) since 1992. He was the editor of the Cahiers québécois de démographie from 2000 to 2005 and president of the Association des démographes du Québec between 2011 and 2015. His research interests include historical demography, history of the Quebec population, analysis of genealogical data and population genetics.

Correspondence to: Département des sciences humaines et sociales, Université du Québec à Chicoutimi, 555, boul. de l'Université, Chicoutimi (Québec), Canada G7H 2B1. Email: marc_tremblay@uqac.ca 
Figure 1. The province of Quebec and its seventeen regions

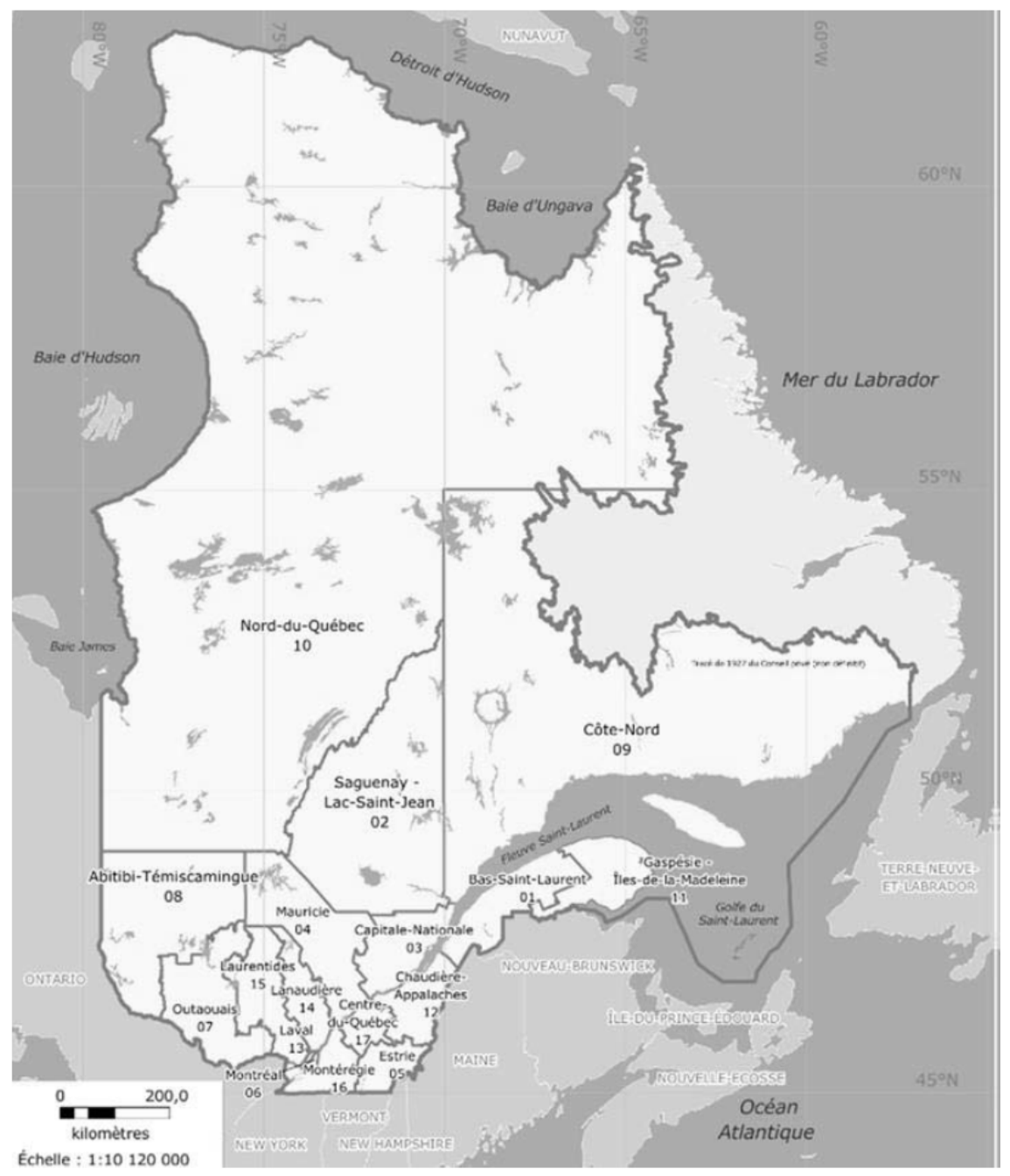

Source: Institut de la Statistique du Québec. 
Table 1. Distribution (\%) of Quebec paternal lines according to the type of change between contemporary and original surnames, by region

\begin{tabular}{llcccccc}
\hline $\mathbf{N o}^{\mathbf{a}}$ & Region & None & Minor $^{\mathbf{b}}$ & Major $^{\mathbf{c}}$ & Subtotal $^{\mathbf{d}}$ & Total & generations $^{\mathbf{e}}$ \\
01 & Bas-Saint-Laurent & 71.0 & 11.3 & 17.7 & 29.0 & 100.0 & 8.2 \\
02 & Saguenay-Lac-Saint-Jean & 79.7 & 7.0 & 13.3 & 20.3 & 100.0 & 8.8 \\
03 & Capitale-Nationale & 73.3 & 9.0 & 17.7 & 26.7 & 100.0 & 8.7 \\
04 & Mauricie & 62.0 & 16.3 & 21.7 & 38.0 & 100.0 & 8.4 \\
05 & Estrie & 64.3 & 15.7 & 20.0 & 35.7 & 100.0 & 8.8 \\
06 & Montréal & 63.3 & 14.0 & 22.7 & 36.7 & 100.0 & 8.1 \\
07 & Outaouais & 55.7 & 20.3 & 24.0 & 44.3 & 100.0 & 8.4 \\
08 & Abitibi-Témiscamingue & 64.1 & 17.1 & 18.8 & 35.9 & 100.0 & 8.6 \\
09 & Côte-Nord & 75.2 & 11.7 & 13.1 & 24.8 & 100.0 & 7.8 \\
10 & Nord-du-Québec & 68.6 & 12.4 & 19.1 & 31.4 & 100.0 & 8.7 \\
11 & Gaspésie-IDLM & 72.6 & 17.4 & 10.0 & 27.4 & 100.0 & 7.4 \\
12 & Chaudière-Appalaches & 76.7 & 9.0 & 14.3 & 23.3 & 100.0 & 8.8 \\
13 & Laval & 60.4 & 18.8 & 20.8 & 39.6 & 100.0 & 8.5 \\
14 & Lanaudière & 60.3 & 13.7 & 26.0 & 39.7 & 100.0 & 8.2 \\
15 & Laurentides & 58.5 & 18.1 & 23.4 & 41.5 & 100.0 & 8.8 \\
16 & Montérégie & 66.3 & 15.0 & 18.7 & 33.7 & 100.0 & 8.1 \\
17 & Centre-du-Québec & 66.6 & 16.7 & 16.7 & 33.4 & 100.0 & 8.5 \\
\hline
\end{tabular}

\footnotetext{
${ }^{\mathrm{a}}$ Region numbers as shown in Figure 1.

${ }^{\mathrm{b}}$ Minor spelling variation with no or with only a slight difference in the pronunciation of the surname.

${ }^{\mathrm{c}}$ Major variations in spelling and pronunciation.

d Total of minor and major changes.

e Mean number of generations between the contemporary subject and his/her paternal immigrant ancestor.
} 
Table 2. Examples of patronymic changes in the Quebec genealogies

\begin{tabular}{|c|c|c|c|c|c|}
\hline gen. $^{a}$ & surname & gen. & surname & gen. & surname \\
\hline 0 & ARBOUR & 0 & AYOTTE & 0 & BELL \\
\hline 1 & ARBOUR & 1 & AYOTTE & 1 & BELL \\
\hline 2 & ARBOUR & 2 & AYOTTE & 2 & BELLE \\
\hline 3 & ARBOUR & 3 & AYOTTE & 3 & BEL LAGRENADE \\
\hline 4 & HARBOUR & 4 & AYOTTE & 4 & BEL LAGRENADE \\
\hline 5 & HARBOUR & 5 & AYOTTE & 5 & BEL \\
\hline 6 & HARBOUR & 6 & AYOTTE & 6 & BEL \\
\hline 7 & HARBOUR & 7 & AYOT & & (Franche-Comté, France) \\
\hline 8 & $\begin{array}{l}\text { HARBOUR } \\
\text { (Normandie, France) }\end{array}$ & $\begin{array}{l}8 \\
9\end{array}$ & $\begin{array}{l}\text { HAYOT } \\
\text { HAYOT } \\
\text { (Perche, France) }\end{array}$ & & \\
\hline 0 & BERNARD & 0 & BERNATCHEZ & 0 & BLANCHETTE \\
\hline 1 & BERNARD & 1 & BERNATCHEZ & 1 & BLANCHETTE \\
\hline 2 & VENE BERNARD & 2 & BERNATCHEZ & 2 & BLANCHETTE \\
\hline 3 & VENE BERNARD & 3 & BERNATCHEY & 3 & BLANCHETTE \\
\hline 4 & VEVES & 4 & BERNECHE & 4 & BLANCHET \\
\hline 5 & $\begin{array}{l}\text { WEBER } \\
\text { (Franconia, Germany) }\end{array}$ & $\begin{array}{l}5 \\
6 \\
7 \\
8\end{array}$ & $\begin{array}{l}\text { BERNACHEZ } \\
\text { BERNECHE } \\
\text { BERNATCHEZ } \\
\text { BERNECHE } \\
\text { (Gascogne, France) }\end{array}$ & $\begin{array}{l}5 \\
6 \\
7 \\
8 \\
9\end{array}$ & $\begin{array}{l}\text { BLANCHET } \\
\text { BLANCHETTE } \\
\text { BLANCHET } \\
\text { BLANCHET } \\
\text { BLANCHET } \\
\text { (Picardie, France) }\end{array}$ \\
\hline 0 & BOULANGER & 0 & BOURQUE & 0 & CHAMPAGNE \\
\hline 1 & BOULANGER & 1 & BOURQUE & 1 & CHAMPAGNE \\
\hline 2 & BOULANGER & 2 & BOURQUE & 2 & CHAMPAGNE \\
\hline 3 & BOULANGER & 3 & BOURQUE & 3 & CHAMPAGNE \\
\hline 4 & BOULANGER & 4 & BOURQUE & 4 & LAPLANTE \\
\hline 5 & BOULANGER & 5 & BOURG & 5 & LAPLANTE CHAMPAGNE \\
\hline 6 & LEFEBVRE BOULANGER & 6 & BOURG & 6 & LAPLANTE CHAMPAGNE \\
\hline 7 & LEFEVRE BOULENG & 7 & BOURG & 7 & LAPLANTE \\
\hline 8 & LEFEBVRE & & (Acadie, Canada) & 8 & LAPLANTE \\
\hline 9 & $\begin{array}{l}\text { LEFEBVRE } \\
\text { (Île-de-France, France) }\end{array}$ & & & & (Poitou, France) \\
\hline
\end{tabular}


Table 2. Examples of patronymic changes observed in the Quebec genealogies (continued)

\begin{tabular}{|c|c|c|c|c|c|}
\hline gen. $^{a}$ & surname & gen. & surname & gen. & surname \\
\hline 0 & DESCOTEAUX & 0 & ESMOND & 0 & GEMME \\
\hline 1 & DESCOTEAUX & 1 & ESMOND & 1 & GEMME \\
\hline 2 & DESCOTEAUX & 2 & ESMOND & 2 & GEMME \\
\hline 3 & DESCOTEAUX & 3 & HAYISMAN & 3 & GEMME \\
\hline 4 & DESCOTEAUX & 4 & HAYISMAN & 4 & SANSOUSSI \\
\hline 5 & DESCOTEAUX & & (Ireland) & 5 & SANSOUCIS \\
\hline 6 & LEFEBVRE DESCOTEAUX & & & 6 & SANSOUCY \\
\hline 7 & LEFEBVRE DESCOTEAUX & & & 7 & JACQUES SANSOUCY \\
\hline 8 & LEFEBVRE & & & 8 & JAMES SANSOUCY LANGLOIS \\
\hline 9 & $\begin{array}{l}\text { LEFEBVRE } \\
\text { (Île-de-France, France) }\end{array}$ & & & & (Dorset, England) \\
\hline 0 & JOMPHE & 0 & LACHAPELLE & 0 & LAFRANCE \\
\hline 1 & JOMPHE & 1 & LACHAPELLE & 1 & LAFRANCE \\
\hline 2 & JOMPHE & 2 & LACHAPELLE & 2 & LAFRANCE \\
\hline 3 & JOMPHE & 3 & LANGLOIS LACHAPELLE & 3 & DARAGON LAFRANCE \\
\hline 4 & JOMPHE & 4 & LANGLOIS & 4 & DESRAGON \\
\hline 5 & SCHUMPH & 5 & LANGLOIS & 5 & DESRAGON \\
\hline 6 & $\begin{array}{l}\text { SHUMPF } \\
\text { (Rheinland-Pfalz, Germany) }\end{array}$ & $\begin{array}{l}6 \\
7 \\
8\end{array}$ & $\begin{array}{l}\text { LANGLOIS LACHAPELLE } \\
\text { LANGLOIS LACHAPELLE } \\
\text { LANGLOIS } \\
\text { (Île-de-France, France) }\end{array}$ & $\begin{array}{l}6 \\
7 \\
8 \\
9\end{array}$ & $\begin{array}{l}\text { DRAGON } \\
\text { DARAGON } \\
\text { DARAGON } \\
\text { DARAGON } \\
\text { (France) }\end{array}$ \\
\hline 0 & LAFRANCE & 0 & LAFRANCE & 0 & LANGLAIS \\
\hline 1 & LAFRANCE & 1 & LAFRANCE & 1 & LANGLAIS \\
\hline 2 & LAFRANCE & 2 & LAFRANCE & 2 & LANGLAIS \\
\hline 3 & LAFRANCE & 3 & PINEL LAFRANCE & 3 & LANGLAIS \\
\hline 4 & LAFRANCE & 4 & PINEL LAFRANCE & 4 & LANGLAIS \\
\hline 5 & LAFRANCE & 5 & PINEL LAFRANCE & 5 & WABORD LANGLAIS \\
\hline 6 & PHILIPPE LAFRANCE & 6 & LAFRANCE & 6 & OUABART LANGLOIS \\
\hline 7 & DUBOIS & 7 & PINEL & 7 & OUABARD LANGLAIS \\
\hline 8 & DUBOIS & 8 & PINEL LAFRANCE & 8 & OUABARD LANGLOIS \\
\hline 9 & $\begin{array}{l}\text { DUBOIS } \\
\text { (Bretagne, France) }\end{array}$ & $\begin{array}{c}9 \\
10\end{array}$ & $\begin{array}{l}\text { PINEL } \\
\text { PINEL } \\
\text { (Normandie, France) }\end{array}$ & 9 & $\begin{array}{l}\text { OUABARD LANGLOIS } \\
\text { (Massachusetts, New England) }\end{array}$ \\
\hline
\end{tabular}


Table 2. Examples of patronymic changes observed in the Quebec genealogies (continued)

\begin{tabular}{|c|c|c|c|c|c|}
\hline gen. $^{a}$ & surname & gen. & surname & gen. & surname \\
\hline 0 & LAPLANTE & 0 & LEBLANC & 0 & LOUIS SEIZE \\
\hline 1 & LAPLANTE & 1 & LEBLANC & 1 & LOUIS SEIZE \\
\hline 2 & TESSIER LAPLANTE & 2 & LEBLANC & 2 & LOUISEIZE \\
\hline 3 & TESSIER LAPLANTE & 3 & LEBLANC & 3 & LOUIS SEIZE \\
\hline 4 & TESSIER LAPLANTE & 4 & HILDEBRAND & 4 & LOUIS SEIZE \\
\hline 5 & TESSIER LAPLANTE & 5 & HILDEBRAND & 5 & LOUISEIZE \\
\hline 6 & TESSIER LAPLANTE & 6 & HILDEBRAND & 6 & LOUISSEIZE \\
\hline 7 & TESSIER LAPLANTE & 7 & HILDEBRAND & 7 & SEIZE \\
\hline 8 & TESSIER & & (Germany) & & (Lorraine, France) \\
\hline 9 & $\begin{array}{l}\text { TESSIER } \\
\text { (Poitou, France) }\end{array}$ & & & & \\
\hline 0 & MASSON & 0 & PERREAULT & 0 & PLANTE \\
\hline 1 & MASSON SERRURIER & 1 & PERREAULT & 1 & PLANTE \\
\hline 2 & MASSON SERRURIER & 2 & PERREAULT & 2 & PLANTE \\
\hline 3 & SERRURIER & 3 & PERREAULT & 3 & PLANTE \\
\hline 4 & SERRURIER & 4 & PERREAULT & 4 & LAPLANTE \\
\hline 5 & SERRURIER & 5 & PERREAULT & 5 & BONNIER LAPLANTE \\
\hline \multirow[t]{4}{*}{6} & SERRURIER SELOZ & 6 & PERRAULT & 6 & LAPLANTE LABOURLIERE \\
\hline & (Germany) & 7 & PERREAULT & 7 & LAPLANTE \\
\hline & & 8 & PERRAULT & 8 & LAPLANTE \\
\hline & & 9 & $\begin{array}{l}\text { PERRAULT } \\
\text { (Bourgogne, France) }\end{array}$ & 9 & $\begin{array}{l}\text { LABOURLIERE LAPLANTE } \\
\text { (Poitou, France) }\end{array}$ \\
\hline 0 & SANSCARTIER & 0 & SMITH & 0 & THISDELLE \\
\hline 1 & SANSCARTIER & 1 & SMITH & 1 & THISDELLE \\
\hline 2 & SANSCARTIER & 2 & SMITH & 2 & THISDELLE \\
\hline 3 & PESANT SANSCARTIER & 3 & SMITH & 3 & THISDEL \\
\hline 4 & PESANT SANS CARTIER & 4 & SMITH & 4 & THISDEL \\
\hline 5 & PESANT & 5 & SCHMID & 5 & THISDALE NOEL \\
\hline 6 & PESANT & 6 & SCHMID & 6 & NUHALTE \\
\hline 7 & $\begin{array}{l}\text { PAYSAN } \\
\text { (Poitou, France) }\end{array}$ & 7 & $\begin{array}{l}\text { SCHMID } \\
\text { (Germany) }\end{array}$ & & (Yorkshire, England) \\
\hline
\end{tabular}

\footnotetext{
${ }^{a}$ Generation numbers in paternal lines, from the subjects (0) to the immigrant ancestor (4 to 10). Regions/countries of origin are those of the immigrant ancestors.
} 